Atabay B.A., Koptyleuova D.T.

Image of ancient Turkic words in Kazakh language

Атабай Б.А., Көптілеуова А.Т.

Қазақ тімінде сақталған көнетүркі сөздерінің келбеті

Атабай Б.А., Коптилеуова А.Т.

Эмементы древнетюркской лексики в современном казахском языке
The vocabulary of modern Kazakh language originates from the Turkic formation. The basis of the phonological structure of the Kazakh language is also drenetyurksky language proof materials are of ancient Turkic written monuments. A number of vocabulary included in the "Divan lugat am Turk" Mahmud Kashgar, one of the greatest of the ancient Turkic written monuments in the XI XII., Is found in the modern Kazakh language. Many elements of the Kazakh language drevnetyukrskie preserved primitive form, the Turkic root. Turkic root is naidrevneyschaya historical and real unit of language, which has preserved its essence despite constant phono-morpho-semantic change, occurring in the course of building aglyunativnogo Turkic languages.

Key words: modern Kazakh language, ancient Turkic written monument, M.Kashgari.

Қазіргі қазақ тілінің сөздік қоры жалпы түркілік қабаттан өрістейлі. Оның негізі, сөздік қоры, фонологиялық құрылысы ежелгі түркі тілінен бастау алатынына көне түркі жазба ескерткіштеріндегі лексикалар дәлел бола алады. XI-XII ғ. жазылған түркі жазба ескерткіштерінің бірі М.Қашқаридің “Аиуан луғат ат-түрк» атты еңбегіндегі көптеген сөздер қазіргі қазақ тілінде сақталған. Қазақ тіліндегі көнетүркілік элементтердің арасында кейпін бұзбай сақталғандары Аа бар. Түркі тілдерінің барлығына тән заңдылық-аглюнативтік даму үАерісінде үнемі болып отырған фоно- морфологиялық өзгерістерге қарамастан, көне әрі тілдік тарихи бірлік болып саналатын түбір өзінің негізін сақтап қалған. Ол түбірлер қазіргі қазақ тілінде Ае бар.

Түйін сөздер: қазіргі қазақ тікі, көнетүркі жазба ескерткіштері, М.Қашқари.

Словарный состав современного казахского языка берет свое начало от общетюркского пласта. Основой фонологической структуры казахского языка также является Аренетюркский язык, Аоказательством того служат материалы из письменных Аревнетюркских памятников. Определенное число лексики, вкАюченной в "Аиван мугат ат турк» Махмуда Кашгари, одного из величайших из древнетюркских письменных памятников XI XIIв., встречается в современном казахском языке. Многие древнетюкрские элементы казахского языка сохранили первообразную форму, тюркский корень. Тюркский корень есть наидревнейщая и историческая реальная единица языка, сохранившая свою суть несмотря на постоянные фоно-морфо-семантические изменения, происходящие в процессе аглюнативного развития строя тюркских языков.

Ключевые слова: современный казахский язык, Аревнетюркский письменный памятник, М. Кашгари. 


\section{IMAGE OF ANCIENT TURKIC WORDS IN KAZAKH LANGUAGE}

Reach Kazakh language vocabulary is obliged to Turkish language. From the historical sources, before becoming an independent nation Kazakhs survived together with other Turkic nations. That is why the vocabulary of the Kazakh language derived from the Turkish language. Composition of a word, phonological structure originates from the Turkish language $[1,88]$. The ancient elements show historical development of Turkic languages, these elements originate ancient Turk period and can be met in written literature which are saved to our days.

Now common Turkic borrowings in Kazakh language is consist of root and historical words. We can rebuild them and show ancient form by historical comparison of words [2, 24]. By comparing an ancient Turkic literature and a modern Kazakh language we can discover old phonetic forms of words, the structure and semantically development.

By discovering borrowed Turkic roots, we have full opportunity to discover the development of roots of words in Kazakh language. Academician A. Kaidar wrote: «Тюркский корень есть наидревнейщая и историческая реальная единица языка, сохранившая свою суть несмотря на постоянные фоно-морфо-семантические изменение, происходящие в процессе аглюнативного развития строя тюркских языков. Он может структурно совпадать с первообразным словом, если оно не превышает одного слога» [3, 24].

Referring to this statement, we tried to discover Turk literature of XI-XII centuries and modern Kazakh words by historical comparing. In order to make a survey to the Turkic borrowed words we took "Dyuan lugat at Turk" of M. Kashgari to discover. All the mentioned words in the vocabulary belong to Turkic nations but this work was written in Arabic.

This work was written in XI century and preserved to our days, one of the Turkic old literatures. A.N. Konanov said that the main aim of writing "Divan" in Arabic was the raise of status of the Turkish language $[4,138]$. In order to show the status of Turk language M. Kashgari alluded to Hadith of Prophet Muhammad: Learn Turkic languages, because their power will be long" $[5,1]$. 
This work is the most valuable source for experts in Arab studies because it was written in Arabic. Z.N Nadzhip wrote: “Словарь содержит грамматический очерк и представляет большой интерес не только для тюркологов, но и для арабистов" [6, 619]. During the process of writing of "Divan" M. Kashgari tried to keep the method of Al-Farahidi. This was mentioned in the author's note: "In order to show the equality of Turkish language with Arabic, I used to write all the words not in use by the method of Al-Farahidi in "Kitab ul-Ain". But my aim was to find an appropriate word and to make people use them. That is why I dropped all the words not in use and left only the words those are in active use. I am keeping right way" $[5,34]$.

Khalil bin Ahmed al-Farahidi (791) is considered to be the father of the Arabic philology. The history of Arab lexicography started from "Kitab ul-Ain". M. Kashgari knew that he may damage the content of the dictionary that is why he followed the way of Abu Ibrahim Ishaq al-Farabi in work «Divan Al-Adab» [7, 209].

The influence of work of al-Farabi on Kashgari dictionary can be seen in the name of the work - "Divan". Similarity of these two works is based on the same methodic.

The main structural difference of "Divan AlAdab" of Al-Farabi is morphological segmentation method. In order to make it clear in Kazakh language we can give an example: жап, тап, қап, сап; жақ, бақ, сақ, нақ. In Arab lexicography this method is called Al-Kafiya and means consonance.

Turkic words were also formed by this method in Kashgari's "Divan", the rule of keeping the last letter the same was strictly enforced in all 8 parts of the dictionary. For example: the first part - the book (the author used to call each part a book) contains words that begin from hamza, in the chapter of words with two consonants is also made by the method of morphological segmentation, for example:

$$
\begin{aligned}
& \text { Б. } \boldsymbol{A \sigma}, \boldsymbol{y} \boldsymbol{y}, \\
& \text { Т. } \boldsymbol{A m}, \boldsymbol{y m}, \boldsymbol{u m} \text {. } \\
& \text { Ж. } \boldsymbol{A} \boldsymbol{x}, \boldsymbol{y} \boldsymbol{c} \\
& \text { Р. } \boldsymbol{A p}, \boldsymbol{u p} .
\end{aligned}
$$

From the site of Kazakh morphology we can see only one vowel and one consonant word. If we take into account that this dictionary was formed by Arab lexicography the examples which were given above $a, y, u$ sounds belongs to hamza in
Arab alphabet and this part is called "the book of words begin from hamza".

We started to discover one syllable words in order to fine correspondences with Kazakh language within the words which were formed by the method of "Al-Kafiya". On syllable words are root of the word that is why it gives us a full opportunity to come closer to protolanguage.

Some of the words from hamza book can be seen in modern Kazakh language, for example $\mathrm{OH}$, $Y_{H}, \chi^{H}, i H, e H, o \check{u}$. If we transliterate these words we will have transformations like $O H, Y H, Y^{H}$ into $y н, і н$, ен into $и н$, ой into $y \check{u}$ because there were only 3 consonants a,у, и in old Turkic language.

By the imperative of modern time, environmental and people change the number of consonants was enlarged. This was written in the statement of $\mathrm{Zh}$. Aralbayev «B древнетюркский период существовало только три гласных фонемы (a,y, и). Слова с другими гласными относятся к более позднему периоду развития языка, т.е. период фонетических изменений, заимствований. Среднетюркский период характеризуется становлениями гласных Y, e, i» (8.120-121 p).

Scientists discovered the sound y and conclude that this sound is absolutely used in the beginning of the word. Scientist, investigator of Kazakh sounds $\mathrm{Zh}$. Aralbayev announced that y sound by phonetical rules of Kazakh language is transformed into $X$ or $Y$ sounds and the second insignificant component y (тау) sound very short.

In ancient times the sound y was placed absolutely in the beginning, in the first and in the second syllables and now it is equal to modern Kazakh sounds $Y, \ngtr$, о, ө, ы. That is why three words that were given in Kashgari's "Divan" in type of أون adopted in Kazakh language as $о H, Y^{H}$, $Y^{H}$ we can surely say that this is fully correspond by context. This conclusion can also refer to the words $i H, e H$.

All the example above were given in "Esim" book (also called chapter), if we pay attention to one syllable word in the part of "verbs" in this book, these words can phonetically change but semantically they keep their original form in Kazakh language: уб- өбу (ул мани убди- ол мені өпті). Уж-ұш (куш ужди - құс ұштыл). Ужөш(ут ужди от өшті). Ар тини ужди - ердің (ер адамның) тынысы өшті . Ур-ул ут урди( ол отты үрледі).Ур-алкиндаки наңни йирда урди (ол қолындағысын жерге қойып ұрды). Уз-ул йиб 
узди(ол жіпті үзді). Ук-ул ар ишни уқұди (бұл кісі өз ісін ұқmbl, түсінді). Ун-ут унди ( шөп өнді (өсті). Ут - ул ани утти (ол оны ұтты). Ут-уқ кайиктан утти- оқ киіктен өтті. Қарин утти - іш өтті. Ур-ул саж урди - ол шаш өрді. Ур-ул ут урди-ол шөп шапты. Уз - аник ати узди (оның аты озды). Уй-ул қағун уйди - ол қауынды ойды. Уй - ул униғ уйди - ол ұнды үйді.

Modern Kazakh language has a little difference in phonetics and we can see the way of transformation an old Turkic sound into modern Kazakh language уж-ұш, уж-өш, ур-үр, ур-ұр, ут-ұт, уз-оз, ут-өт, уз-үз, уй-ой, уй-үй уң-уңгі. When we discovered the words which have kept two eras we defined that the sound y is articulatory changeable and that this sound is changed into $¥$, Y, o, $ө$, e, b sounds in our modern language. Old Turkic words with y sound were transformed into $y-\nsucceq$, this can be seen in the following examples:

Кут- قت құт (luck, reverse of a fortune) ( 9. 315-page)

Кузкуз maz, he sun shines on it only after noon, as it is on the left side of the sun. (9.319-page)

Куш-شُش құc [kus] burd

Кул- -⿳⺈冂大

Кум-قُ құм [kum] sand

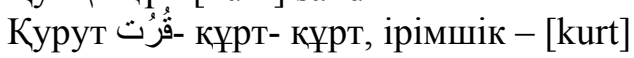

Туқ-тоқ. Туқ киши -тоқ кісі [fat or full]

Қурт -құрт. All Turkic nations use this word and this means (insect).

Кубуз-қобыз. [kobyz]

Булуш-болыс/ ул маңа булуш қилди - ол маған болысты. He helped me.

Туруқ-арық. This is paired word and in Kazakh language is used vice a versa- арық тұрық.

Тузақ-тұзақ. [tuzak] trap

There are also old Turkic y sound words that were transformed into $\mathrm{y}-\mathrm{o}$ sound in modern Kazakh language. sheep.

Қуй قو-қой. Қуй йили-қой жылы. Year of

Қур-қор. Ferment of kumyz. (9. 831).

Кул-қол. [kol] hand.

Кум-қом (түйенің қомы) [kom] back fat of camel.

Буз-боз. Боз ат, боз қой.

Буш-бос. Empty.

Кун-қон. Куш қунды құс қонды.

Relying on these examples we can conclude that the sounds $y, \ngtr, o$ are close from the genetic site. Sounds $¥$, o were derived from the sound y of protolanguage. That is why we can see similarities in y-o sounds (1.72). In the long history of Turkic languages the development of sounds can be seen by such similarities. The development of sounds is based on development of language, sounds were changed $y-0, y-¥$, these sounds $y-0-\theta, y-z-Y$ were derived.

We faced with this phenomenon when we compared lexisof Kashgari dictionary and materials of Kazakh language. For example:

бур-бүр, тур-түр (түру), туш-түсу,

Кун - ن' күн. Кун тугди. Күн туды. Кунка бақса куз қамар - күнге кім қараса, соның көзін қариды. 330-р.

Кун- نُ์күн (бу кун барғил) - бүгін бар [kun] sun

Бурк- بُرك бөрік. In order to show the meaning of this word Kashgari gave the next proverb: Татсиз турк булмас, бамсиз бурк булмас Turk cannot survive without Persian (Tat), head without fur cup. (336-p)

Туз-ثُ түз (түзу бірдеңе, туз йир-түзу жер level ground

Куз-زร́-күз, autumn

Туш- ثُ- түс (түсетін уақыт пен жер) afternoon

Кумуш-күміс - silver

Кумаж-көмеш/ күлде пісірілген нан (күлше).

If we pay attention to the statement of turcologist D.G. Kiyekbayev who worked on development of consonants in Turkish language, disappearance of ancient consonants started from open syllable $0, \Theta$, . . As a result vowels with slurred length disappeared and formed narrow vowels у,Ү,и.

These changes in some Turkish languages lead to the formation of $0, \Theta, \partial$ (e) narrow vowels and changed ancient $y, \ddot{y}, i$ consonants. Narrowing of open syllable $o, \ddot{a}$, a to a degree of $y, y, u$ pushed out ancient $y, \ddot{y} i$ consonants. The process of narrowing can be seen in similarities of y-ы sounds in comparison of M. Kashgari dictionary and Kazakh language. For example: Булға-былға or pollute. Ол сувун булғады. Ол суды былғады - He polluted water.

The word қавун in dictionary was changed into қ̧aybl - muskmelon because the sound $z$ had fallen out and left қаун. But in Kazakh language this word exposed to epenthesis and changed into қ̧ayblн, because there is no any sound like $(y \mu)$. 
This change is called vowel harmony; sound $\mathcal{z}$ pushed out $\mathrm{y}$ and is exposed to epenthesis, so sound $z$ is not changed with $y$.

Change of sound $z$ by the influence of vowel harmony law can be seen in next examples: жыла, туды, бура, құман, тамақ. Old phrases like кун тувды, жузла, бугра were transformed and now have new shapes. There are a lot of examples of transformations of weak $z$ sound: in words кумzан, тамzақ the sound $z$ fell out and these words turned into new shapes.

Авыз, савлық, савым, аурия, йамав, тав words were transformed and adopted into aybls, саулық, сауым, ауру, жамау, тау (9.92).

The process of changing of sound $\mathcal{z}$ is described by B. Sagindykuly. In YI-XIY c. this sound like sounds $\kappa, \kappa, \Gamma$ had a priorities of saving and felling out in word structure. Now guttural sounds are fully pushed out because of change of raised sounds with blackness sounds.

In the following example we can observe changes of linguistic factors while comparing variants from Divan and Kazakh language (Turkic languages).

B. Sagindykuly announced that sounds $K, \mp, K, \Gamma$ were fallen out in the middle of the word more than in the end of the word.

We tried to compare the transformation of words тушағ (9.387- page), қирағу, бузағу, бушуғу, тушағу (417-page), тумағу from dictionary with modern Kazakh language use.

This was adopted the next way: the sound y just moved forward to the place of fell sound $z$ because it was the last sound that is why it did not need any epenthesis:

$$
\begin{aligned}
& \text { қирағу } \rightarrow \text { қырағу } \rightarrow \text { қырау; }- \text { frost } \\
& \text { бузагу } \rightarrow \text { бузағ } \rightarrow \text { бузау } \rightarrow \text { бұзау; - calf } \\
& \text { тумағу } \rightarrow \text { тумау } \rightarrow \text { тұмау - cold. }
\end{aligned}
$$

All the matches of $\mathrm{F}-\mathrm{y}$ in examples above B. Sagindykuly offered to consider it as a coincidence (10.62).

The sounds $u-c$ are changeable because they have the same origin. This coincidence is the most frequently occurring phenomenon in Turkic languages. M. Kashgari warned that Turkic languages have differences in sounds, for example, Kipchaks used sound $u$ instead of $c$. Kazakh language belongs to the Kipchak group of languages and we started to study the difference between modern Kazakh language words and the words from dictionary because of $\amalg-c$ sounds similarities.
The one word in M. Kashgari dictionary which stays without any figural and contextual changes is iнi (brother). This word has another meaning in some other Turkic languages. For example, in Usbek dialects this word means brother, in Turkmen language means nephew, in Turk dialects this means sister, in Manchurian-Tungusic languages means in-law. (11. 363). Here we should point out that Kazakh word brother-in-law is similar by context.

Word kapbls (loan) is a borrowing word from Arab language and in modern Kazakh spoken language is used like debt. Equivalent of load in M.Kashgari dictionary is бирим that is бepim(refund) in Kazakh language. Taking into account the word formation in Kazakh language verb aлy to take formed - алым- receipts, the verb өну - to develop formed өнім - product, the verb өcy - to grow formed өсім - growth, the verb бiлy - to know formed бiлin - knowledge, the word бupuм is formed from the verb to give and there is no doubt that this word is transformed into modern use қарыз - debt. There is an illustrational material for the word берім: Алимжи арслан, биримжи сижган (9.385). A borrower is lion, a person who repays money is mouse.

There is a huge similarity in use of $\sigma-\mu$ sounds between modern Kazakh language and language of XI century. By the influence of phonemes б, त to $H$ phoneme appeared allophone $M$. The main reason for the change of sounds $\mathrm{b}$ and $\mathrm{m}$ is lip adhesion when speaking. For example: бижин- bizhin. M.Kashgari defined this word as a year chronology. In Kazakh language it is used like $\boldsymbol{\text { ne- }}$ шін - [meshin] - monkey and there is a year of monkey in Kazakh chronology.

Word саман in the dictionary can also refer to the example of $\sigma-\mu$ sounds similarity. M.Kashgari defined the origin of this word came from Chigil language and now it is used like сабан - [saban]straw. Another examples are бұз-мұз - [muz] - ice, бузлуқ-мұздық [muzdyk] iceberg, сузма-сүзбе [suzbe] curd, бурун-мұрын [murin] nose. There is a great proverb Буздан сув тамар - мұздан су maмap - water drips from ice. M.Kashgari used this proverb when someone character is the same like father's character (9.832).

Words батман, катман are additional examples of $\sigma-\mu$ sounds similarity. They were transformed like батпан [batpan], кетпен [ketpen]. We should understand that these changes is made by vocalic harmony law. 
Examples of $3 / \breve{u}[z, i]$ sounds similarity can be seen in the next word: қ̧aŭzbl [kaugu] grief is formed from қ̧aзzy (9.398). This was written in work of Kashgari: йағма, тухсу, қыпшақ, ябақу, татар, қай, чумул that mean Ogus use 3 [z] instead of $\breve{u}[i]$ and never use sound $\partial_{3} \dot{j}$ [dz]. When others call birch as қ̧адзық [kadzyk] this tribe calls қ̧aŭblu [kayin] birch, if they call in-laws as құадзын [kadzin] this tribe calls қ̧айын [kayin] in-law. The sound $\partial_{3}$ [dz] which is used by Chingil and other Turkic tribes changed into the sound $3[z]$ by Kipchak, Yamak, Subar Bulgar and tribes that lived in the territories near Rus and Rome. Turks used to call a leg адзақ [adzak], they call it aзақ [azak]. Use of pronouns and verbs can be understood by these examples. Concluding the sound $\partial з[d z]$ of Chingil is equal to $\breve{u}$ [i] which was used by Argus who lived in the territories from Yamga, Tuhsci, Ogus to China (some Kazakh scientist describes China as Chin, if we consider that Chaina in Arab language is Sin, Sin should be Kazakh equivalent of China) and also correspond with sound $3[z]$ which was used by tribes who lived till the territory of Rome(9.71).

Now we should make a step back. Discovering M.Kashgari's works Kazakh scientist made a mistake conserning Argus: "local tribes till the territory of Chin used sound й [i]" (1.4748,12.101). Couse of this mistake is understandable because scientist read Kashgari dictionary in Turkish translation, so word бazзы [bagzu] in Turkish language means some in Arab language. Arab borrowing in Turkish language are on more use than in Kazakh language, words which contain sound д (ض) [d] is changed in to sound $3[z]$.

Similarity of Kazakh and old Turkic languages are on use of $\varkappa-u$ [zh-sh] sounds. The sound $\varkappa$ [zh] is changed into $u$ [sh] in Kazakh language: Қамжи-қамшы, кижик-кішік - yanger. Жажакшешек is given as flower but it has two meanings in Kazkah language, the first is name of flower and the second is contagious skin disease but now it does not used in medicine. Word Сижған [Sizhgan] is transformed like тышқан - mouse.

There a full of words that have kept its original form. For example: талақ (көк бауыр), тылақ, бұлан, сірке, сірке су, терек, тілек, бөрік, қырық, көрік (korik-equipment of blacksmith another meaning korik-beauty), қымыз, балық, тұзақ, құлақ, қатық, қылық.

There are recognizable words through sound similarity: бишик - бесік, қавук-куық, қашуққасық, кунуқ-қонақ, бижақ, билак-білек, тирактерек, тилак-тілек, бурка-бүрге, тушак-төсек, тишак-тұсақ, талик-тілік, тазак-тезек, кабак-кебек, сидук-сідік, кубук-көбік, казик-кезек, кунак-көнек, касак-кесек.

In conclusion, Kazakh vocabulary takes its origin from ancient Turkish language, the more it develops the deeper roots.

\section{Әдебиеттер}

1. Мұрат Сабыр. Орта түркі тілі лексикасы мен қазақ тілі лексикасының сабақтастығы. - Алматы: Қазақ университеті, 2004

2. Манкеева Ж.А. Мәдени лексиканың ұлттық сипаты.-Алматы: «Ғылым»,1997.

3. Кайдаров А.Т. Структура односложных корней и основ в казахском языке. - Алма-Ата, 1986.

4. Кононов А.Н. Махмуд Кашгарский о тюркских языках. В книге: История лингвистических учений. Средневековый восток. - Ленинград: «Наука», 1981.

5. Қашғари Махмуд. Диуан луғат ат-турк. - Анкара, 1990.

6. Наджип 3.Н. Заслуги арабских филологов в области изучения тюркских языков. В книге: Семитские языки. - М., «Наука», 1985

\section{Referense}

1. Murat Sabyr. Orta turki tili leksikasy men kazak tili leksikasynyn sabaktastygy.- Almaty: Kazak universiteti, 2004

2. Mankeeva Zh.A. Madeni leksikanyn ulttyk sipaty. - Almaty: «Gylym»,1997.

3. Kajdarov A.T. Struktura odnoslozhnyh kornej i osnov v kazahskom jazyke. - Alma-Ata, 1986.

4. Kononov A.N. Mahmud Kashgarskij o tjurkskih jazykah. V knige: Istorija lingvisticheskih uchenij. Srednevekovyj vostok. - Leningrad: «Nauka», 1981.

5. Kashgari Mahmud. Diuan lugat at-turk. - Ankara, 1990.

6. Nadzhip Z.N. Zaslugi arabskih filologov v oblasti izuchenija tjurkskih jazykov. V knige: Semitskie jazyki. - M., «Nauka», 1985 